\title{
HUBUNGAN PENGETAHUAN, SIKAP DAN PERILAKU DENGAN KEPATUHAN IBU RUMAH TANGGA DALAM PENCEGAHAN COVID-19 DI RT 02 RW 05 KABANDUNGAN I DESA SIRNAGALIH BOGOR
}

\author{
Andina Bunga Syafel ${ }^{1}$ dan Anissatul Fatimah ${ }^{2}$ \\ andinabungas@gmail.com ${ }^{1}$ \\ anissatulfathimah@gmail.com ${ }^{2}$ \\ Fakultas Ilmu Kesehatan Universitas Ibn Khaldun Bogor ${ }^{1,2}$
}

\begin{abstract}
Covid-19 is an infectious disease caused by a new type of coronavirus discovered in 2019, hereinafter referred to as SARS-Cov 2 (Severe Acute Respiratory Syndrome Coronavirus-2). The purpose of this study was to determine the relationship between knowledge, attitudes and behavior with housewives' compliance in preventing Covid-19 at RT 02 RW 05 Kabandungan I Sirnagalih Village, Tamansari District, Bogor. This study uses a type of research, namely correlation analysis. The population in this study were all housewives in RT $02 R W 05$ Kabandungan I Sirnagalih Village, Tamansari District, Bogor totaling 120 people. The sampling technique in this study was total sampling so that the sample in this study was 120 respondents. Test data analysis using chi square and logistic regression. The results of statistical tests with chi square showed that there was no relationship between age and adherence (pvalue=0.336). There is no relationship between education and adherence (pvalue=0.140). There is no job relationship with compliance (pvalue=0.093). There is a relationship between knowledge and compliance (pvalue=0.024). There is a relationship between attitude and compliance (pvalue=0.002). There is a relationship between behavior and compliance (pvalue =0,000). Meanwhile, with the multivariate test there is a relationship between attitude and compliance and there is a relationship between behavior and compliance. It can be concluded that there is a relationship between attitude and compliance with housewives in preventing Covid-19 and there is a relationship between behavior and compliance with housewives in preventing Covid-19.
\end{abstract}

Keyword : Individual characteristics, knowledge, attitudes, behavior, compliance

\begin{abstract}
ABSTRAK
Covid-19 adalah penyakit infeksi yang disebabkan oleh coronavirus jenis baru yang ditemukan pada tahun 2019 yang selanjutnya disebut SARS-Cov 2 (Severe Acute Respiratory Syndrome Coronavirus-2). Tujuan dari penelitian ini adalah untuk mengetahui hubungan pengetahuan, sikap dan perilaku dengan kepatuhan ibu rumah tangga dalam pencegahan Covid-19 di RT 02 RW 05 Kabandungan I Desa Sirnagalih Kecamatan Tamansari Bogor. Penelitian ini menggunakan jenis penelitian yaitu analitik korelasi. Populasi dalam penelitian ini adalah semua ibu rumah tangga di RT 02 RW 05 Kabandungan I Desa Sirnagalih
\end{abstract}


Kecamatan Tamansari Bogor sejumlah 120 orang. Teknik pengambilan sampel dalam penelitian ini adalah total sampling sehingga sampel dalam penelitian ini sejumlah 120 responden. Uji analisis data menggunakan chi square dan regresi logistic. Hasil uji statistik dengan chi square menunujukkan bahwa tidak ada hubungan usia dengan kepatuhan (pvalue=0,336). Tidak ada hubungan pendidikan dengan kepatuhan ( $p$ value $=0,140$ ). Tidak ada hubungan pekerjaan dengan kepatuhan (pvalue=0,093). Ada hubungan pengetahuan dengan kepatuhan (pvalue=0,024). Terdapat hubungan sikap dengan kepatuhan (pvalue $=0,002$ ). Terdapat hubungan perilaku dengan kepatuhan (pvalue $=0,000$ ). Sedangkan dengan uji multivariat ada hubungan sikap dengan kepatuhan dan ada hubungan perilaku dengan kepatuhan. Dapat disimpulkan bahwa ada hubungan sikap dengan kepatuhan ibu rumah tangga dalam pencegahan Covid-19 dan ada hubungan perilaku dengan kepatuhan ibu rumah tangga dalam pencegahan Covid-19.

\section{Kata Kunci : Karakteristik individu, Pengetahuan, Sikap, Perilaku, Kepatuhan}

\section{PENDAHULUAN}

Pada awal akhir tahun 2019 dan awal tahun 2020 dunia dikejutkan dengan adanya virus baru yang menyerang secara massif yang pertama diketahui berasal dari Wuhan Tiongkok. Penyakit ini kemudian menyebar dengan cepat dinegara lain seperti Thailand, Jepang Korea Selatan, Jerman, Singapura, Vetnam dan Amerika serikat (Wu YC, 2020). Awalnya penyakit ini dinamakan sementara sebagai 2019 novel coronavirus (2019-nCoV), kemudian WHO mengumumkan nama baru pada 11 Februari 2020 yaitu Coronavirus Disease (COVID-19) (WHO, 2020).

Covid-19 adalah penyakit infeksi yang disebabkan oleh coronavirus jenis baru yang ditemukan pada tahun 2019 yang selanjutnya disebut SARS-Cov 2 (Severe Acute Respiratory Syndrome Coronavirus-2). Virus ini berukuran sangat kecil (120- $160 \mathrm{~nm})$ yang utamanya menginfeksi hewan termasuk diantaranya adalah kelelawar dan unta. Saat ini penyebaran dari manusia ke manusia sudah menjadi sumber penularan utama sehingga penyebaran virus ini terjadi sangat agresif. Penularan penyakit ini terjadi dari pasien positif covid-19 melalui droplet yang keluar saat batuk dan bersin (Han Y, 2020).

Virus ini telah menyebar secara luas di China dan lebih dari 216 negara dan teritori lainnya. Pada 12 Maret 2020, WHO mengumumkan COVID-19 sebagai pandemic (WHO, 2020). Hingga tanggal 8 September 2020 terdapat 27.477.062 kasus dan 896.397 jumlah kematian di seluruh dunia. Tiga negara dengan jumlah kasus Covid-19 tertinggi hingga hari ini yaitu Amerika Serikat, India, dan Brazil (WHO, 2020). Untuk Indonesia data gugus tugas percepatan penanganan COVID 19 pada tanggal 8 September 2020, jumlah yang positif 200.035 orang, sembuh 142.958 dan yang meninggal sudah 8.230 orang, sedangkan di Jawa Barat sendiri sudah ada 13.045 orang terkonfirmasi atau $6,5 \%$ dari seluruh Indonesia dengan yang meninggal ada 283 orang (Satgas, 2020). Di Kota Bogor total hingga saat ini jumlah kasus terkonfirmasi positif Covid-19 mencapai 778 orang dan 35 orang meninggal dunia (Kompas, 2020).

Cara terbaik untuk mencegah penyakit ini adalah dengan memutus mata rantai penyebaran covid-19 melalui isolasi, 
deteksi dini dan melakukan proteksi dasar yaitu melindungi diri dan orang lain dengan cara sering mencuci tangan dengan air mengalir dan sabun atau menggunakan hand sanitizer, menggunakan masker dan tidak menyentuh area muka sebelum mencuci tangan, serta menerapkan etika batuk dan bersin dengan baik (Dirjen P2P Kemkes RI, 2020).

Permasalahan yang didapatkan di masyarakat antara lain adalah terbatasnya pengetahuan masyarakat mengenai tindakan pencegahan virus Covid-19, kurangnya kesadaran masyarakat untuk menggunakan masker ketika keluar rumah, kurangnya pemahaman masyarakat dalam penggunaan antiseptik dan desinfektan

\section{METODE PENELITIAN}

Penelitian ini menggunakan jenis penelitian yaitu analitik korelasi. Dengan pendekatan cross sectional. Desain penelitian ini yaitu dengan membagikan kuesioner. Penelitian ini dilaksanakan mulai dari perencanaan sampai pengambilan data pada bulan September 2020 di RT 02 RW 05 Kabandungan I Desa Sinargalih Kecamatan Tamansari Bogor.

Populasi dalam penelitian ini adalah semua ibu rumah tangga di RT 02 RW 05

\section{HASIL PENELITIAN}

\section{Analisa Univariat}

\section{Gambaran Karakteristik Individu}

Tabel 1 Gambaran karakteristik individu pada hubungan pengetahuan, sikap dan perilaku dengan kepatuhan ibu rumah tangga dalam pencegahan covid-19 di RT 02 RW 05 Desa Sirnagalih Kecamatan Tamansari Bogor pada September 2020

\begin{tabular}{llcc}
\hline Karakteristik & \multicolumn{1}{c}{ Kategori } & f & \% \\
\hline Usia & $\leq 45$ tahun & 63 & 52,5 \\
& $>$ 46 tahun & 57 & 47,5 \\
\hline \multirow{2}{*}{ Pendidikan } & Tinggi & 8 & 6,7 \\
& Rendah & 112 & 93,3 \\
\hline
\end{tabular}

yang baik dan benar, dan ditemukan tidak ada physical distancing di lingkungan.

Berdasarkan latar belakang yang telah diuraikan di atas, maka dapat diambil rumusan masalah sebagai berikut "Apakah ada hubungan pengetahuan, sikap dan perilaku dengan kepatuhan ibu rumah tangga dalam pencegahan Covid-19 di RT 02 RW 05 Kabandungan I Desa Sinargalih Kecamatan Tamansari Bogor?"

Tujuan dari penelitian ini adalah untuk mengetahui hubungan pengetahuan, sikap dan perilaku dengan kepatuhan ibu rumah tangga dalam pencegahan Covid-19 di RT RW 05 Kabandungan I Desa Sinargalih Kecamatan Tamansari Bogor.

Jalan Kabandungan I Desa Sinargalih Kecamatan Taman Sari Bogor sejumlah 120 orang. Teknik pengambilan sampel dalam penelitian ini adalah total sampling. Sehingga sampel dalam penelitian ini sejumlah 120 responden.

Data penelitian diperoleh melalui pengumpulan data primer dan data sekunder. Analisis data menggunakan analisis univariat, analisis bivariat yaitu $c h i$ square, dan analisis multivariat yaitu regresi logistic.

\begin{tabular}{llcc}
\hline Pekerjaan & Bekerja & 3 & 2,5 \\
& Tidak bekerja & 117 & 97,5 \\
\hline
\end{tabular}

Berdasarkan data pada tabel diatas, mayoritas usia responden berada pada usia $\leq 45$ tahun sebanyak 63 orang yaitu $(52,5 \%)$, mayoritas berpendidikan rendah sebanyak 112 orang yaitu $(93,3 \%)$, dan mayoritas pekerjaan responden adalah tidak bekerja sebanyak 117 orang yaitu $(97,5 \%)$. 
Gambaran pengetahuan, sikap dan perilaku dengan kepatuhan ibu rumah tangga dalam pencegahan covid-19

Tabel 2 Gambaran pengetahuan, sikap dan perilaku dengan kepatuhan ibu rumah tangga dalam pencegahan covid-19 di RT 02 RW 05 Desa Sirnagalih Kecamatan Tamansari Bogor pada September 2020

\begin{tabular}{lcc}
\hline \multicolumn{1}{c}{$\begin{array}{c}\text { Variabel } \\
\text { Penelitian }\end{array}$} & Frekuensi & \% \\
\hline Pengetahuan & & \\
Tinggi & 64 & 53,3 \\
Rendah & 56 & 46,7 \\
\hline Sikap & & \\
Positif & 65 & 54,2 \\
Negatif & 55 & 45,8 \\
\hline Perilaku & & \\
Baik & 72 & 60 \\
Kurang baik & 48 & 40 \\
\hline Kepatuhan & & \\
Patuh & 65 & 54,2 \\
Tidak patuh & 55 & 45,8 \\
\hline
\end{tabular}

Berdasarkan data pada tabel diatas diperoleh bahwa mayoritas responden memiliki tingkat pengetahuan tinggi sebanyak 64 orang yaitu $(53,3 \%)$, mayoritas responden memiliki sikap positif sebanyak 65 orang yaitu $(54,2 \%)$, mayoritas responden memiliki perilaku baik sebanyak 72 orang yaitu $(60 \%)$, dan mayoritas responden patuh dalam pencegahan covid-19 sebanyak 65 orang yaitu $(54,2 \%)$.

\section{Analisa Bivariat}

Hubungan usia dengan kepatuhan ibu rumah tangga dalam pencegahan covid-

\section{9}

Tabel 3 Hubungan usia dengan kepatuhan ibu rumah tangga dalam pencegahan covid-19 di RT 02 RW 05 Desa Sirnagalih Kecamatan Tamansari Bogor pada September 2020

\begin{tabular}{|c|c|c|c|c|c|}
\hline \multirow[b]{2}{*}{ Usia } & \multicolumn{2}{|c|}{ Kepatuhan } & \multirow[b]{2}{*}{$\begin{array}{c}\text { Tot } \\
\text { al }\end{array}$} & \multirow{2}{*}{$\begin{array}{c}\text { OR } \\
(\mathbf{9 5 \%} \\
\text { CI })\end{array}$} & \multirow{2}{*}{$\begin{array}{c}\text { Pvalu } \\
\text { e }\end{array}$} \\
\hline & $\begin{array}{l}\text { Pat } \\
\text { uh }\end{array}$ & $\begin{array}{l}\text { Tidak } \\
\text { Patuh }\end{array}$ & & & \\
\hline $\begin{array}{l}\leq 45 \\
\text { tahun }\end{array}$ & 31 & 32 & 63 & 0,655 & 0,336 \\
\hline
\end{tabular}

\begin{tabular}{lcccc}
\hline $\begin{array}{c}>46 \\
\text { tahun }\end{array}$ & 34 & 23 & 57 & $\begin{array}{c}(0,318- \\
1,352)\end{array}$ \\
\hline Total & 65 & 55 & 120 & \\
\hline
\end{tabular}

Hasil uji Chi Square diperoleh nilai pvalue 0,336 maka dapat disimpulkan tidak ada hubungan yang signifikan antara usia dengan kepatuhan ibu rumah tangga dalam pencegahan covid-19.

\section{Hubungan Pendidikan dengan kepatuhan ibu rumah tangga dalam pencegahan covid-19}

Tabel 4 Hubungan pendidikan dengan kepatuhan ibu rumah tangga dalam pencegahan covid-19 di RT 02 RW 05 Desa Sirnagalih Kecamatan Tamansari Bogor pada September 2020

\begin{tabular}{|c|c|c|c|c|c|}
\hline \multirow{2}{*}{$\begin{array}{c}\text { Pendid } \\
\text { ikan }\end{array}$} & \multicolumn{2}{|c|}{ Kepatuhan } & \multirow{2}{*}{$\begin{array}{c}\text { Tot } \\
\text { al }\end{array}$} & \multirow{2}{*}{$\begin{array}{c}\text { OR } \\
(\mathbf{9 5 \%} \\
\text { CI })\end{array}$} & \multirow{2}{*}{$\begin{array}{c}\text { Pval } \\
\text { ue }\end{array}$} \\
\hline & $\begin{array}{c}\text { Pat } \\
\text { uh }\end{array}$ & $\begin{array}{l}\text { Tidak } \\
\text { Patuh }\end{array}$ & & & \\
\hline Tinggi & 2 & 6 & 8 & 0,259 & 0,140 \\
\hline Rendah & 63 & 49 & 112 & $\begin{array}{c}(0,050- \\
1,341)\end{array}$ & \\
\hline
\end{tabular}

\begin{tabular}{cccc}
\hline Total & 65 & 55 & 120 \\
\hline & Hasil uji Chi Square diperoleh nilai
\end{tabular} pvalue 0,140 maka dapat disimpulkan tidak ada hubungan yang signifikan antara Pendidikan dengan kepatuhan ibu rumah tangga dalam pencegahan covid-19.

Hubungan Pekerjaan dengan kepatuhan ibu rumah tangga dalam pencegahan covid-19

Tabel 5 Hubungan pekerjaan dengan kepatuhan ibu rumah tangga dalam pencegahan covid-19 di RT 02 RW 05 Desa Sirnagalih Kecamatan Tamansari Bogor pada September 2020

\begin{tabular}{lcccc}
\hline \multirow{2}{*}{ Pekerjaan } & \multicolumn{2}{c}{ Kepatuhan } & & \\
\cline { 2 - 4 } & Patuh & $\begin{array}{c}\text { Tidak } \\
\text { Patuh }\end{array}$ & Total & Pvalue \\
\hline Bekerja & 0 & 3 & 3 & 0,093 \\
\hline $\begin{array}{l}\text { Tidak } \\
\text { Bekerja }\end{array}$ & 65 & 52 & 117 & \\
\hline Total & 65 & 55 & 120 & \\
\hline
\end{tabular}

Hasil uji Chi Square diperoleh nilai pvalue 0,093 maka dapat disimpulkan tidak ada hubungan yang signifikan antara pekerjaan dengan kepatuhan ibu rumah tangga dalam pencegahan covid-19. 
Perbandingan pekerjaan yang tidak signifikan sehingga OR tidak muncul.

\section{Hubungan pengetahuan dengan kepatuhan ibu rumah tangga dalam pencegahan covid-19}

Tabel 6 Hubungan pengetahuan dengan kepatuhan ibu rumah tangga dalam pencegahan covid-19 di RT 02 RW 05 Desa Sirnagalih Kecamatan Tamansari Bogor pada September 2020

\begin{tabular}{|c|c|c|c|c|c|}
\hline \multirow[b]{2}{*}{$\begin{array}{l}\text { Penget } \\
\text { ahuan }\end{array}$} & \multicolumn{2}{|c|}{ Kepatuhan } & \multirow[b]{2}{*}{$\begin{array}{c}\text { Tot } \\
\text { al }\end{array}$} & \multirow{2}{*}{$\begin{array}{c}\text { OR } \\
(95 \% \\
\text { CI })\end{array}$} & \multirow{2}{*}{$\begin{array}{c}\text { Pvalu } \\
\text { e }\end{array}$} \\
\hline & $\begin{array}{c}\text { Pat } \\
\text { uh }\end{array}$ & $\begin{array}{l}\text { Tidak } \\
\text { Patuh }\end{array}$ & & & \\
\hline Tinggi & 28 & 36 & 64 & 0,399 & 0,024 \\
\hline Rendah & 37 & 19 & 56 & $\begin{array}{c}(0,190- \\
0,838)\end{array}$ & \\
\hline
\end{tabular}

\begin{tabular}{llll}
\hline Total & 65 & 55 & 120
\end{tabular}

Hasil uji Chi Square diperoleh nilai pvalue 0,024 maka dapat disimpulkan ada hubungan yang signifikan antara pengetahuan dengan kepatuhan ibu rumah tangga dalam pencegahan covid-19.

\section{Hubungan sikap dengan} kepatuhan ibu rumah tangga dalam pencegahan covid-19

Tabel 7 Hubungan sikap dengan kepatuhan ibu rumah tangga dalam pencegahan covid-19 di RT 02 RW 05 Desa Sirnagalih Kecamatan Tamansari Bogor pada September 2020

\begin{tabular}{|c|c|c|c|c|c|}
\hline \multirow[b]{2}{*}{ Sikap } & \multicolumn{2}{|c|}{ Kepatuhan } & \multirow{2}{*}{$\begin{array}{c}\text { Tot } \\
\text { al }\end{array}$} & \multirow{2}{*}{$\begin{array}{c}\text { OR } \\
(95 \% \\
\text { CI })\end{array}$} & \multirow{2}{*}{$\begin{array}{c}\text { Pvalu } \\
\text { e }\end{array}$} \\
\hline & $\begin{array}{l}\text { Pat } \\
\text { uh }\end{array}$ & $\begin{array}{l}\text { Tidak } \\
\text { Patuh }\end{array}$ & & & \\
\hline Positif & 44 & 21 & 65 & 3,392 & 0,002 \\
\hline Negatif & 21 & 34 & 55 & $\begin{array}{c}(1,599- \\
7,199)\end{array}$ & \\
\hline Total & 65 & 55 & 120 & & \\
\hline
\end{tabular}

pvalue 0,002 maka dapat disimpulkan ada hubungan yang signifikan antara sikap dengan kepatuhan ibu rumah tangga dalam pencegahan covid-19.

Hubungan perilaku dengan kepatuhan ibu rumah tangga dalam pencegahan covid-19

Tabel 8 Hubungan perilaku dengan kepatuhan ibu rumah tangga dalam pencegahan covid-19 di RT 02 RW 05 Desa Sirnagalih Kecamatan Tamansari Bogor pada September 2020

\begin{tabular}{|c|c|c|c|c|c|}
\hline \multirow[b]{2}{*}{$\begin{array}{c}\text { Perila } \\
\text { ku }\end{array}$} & \multicolumn{2}{|c|}{ Kepatuhan } & \multirow[b]{2}{*}{$\begin{array}{c}\text { Tot } \\
\text { al }\end{array}$} & \multirow{2}{*}{$\begin{array}{c}\text { OR } \\
(\mathbf{9 5 \%} \\
\mathbf{C I})\end{array}$} & \multirow{2}{*}{$\begin{array}{c}\text { Pvalu } \\
\text { e }\end{array}$} \\
\hline & $\begin{array}{c}\text { Pat } \\
\text { uh }\end{array}$ & $\begin{array}{l}\text { Tidak } \\
\text { Patuh }\end{array}$ & & & \\
\hline Baik & 51 & 21 & 72 & 5,898 & 0,000 \\
\hline $\begin{array}{l}\text { Kurang } \\
\text { baik }\end{array}$ & 14 & 34 & 48 & $\begin{array}{l}(2,641- \\
13,172)\end{array}$ & \\
\hline Total & 65 & 55 & 120 & & \\
\hline
\end{tabular}

Hasil uji Chi Square diperoleh nilai pvalue 0,000 maka dapat disimpulkan ada hubungan yang signifikan antara perilaku dengan kepatuhan ibu rumah tangga dalam pencegahan covid-19.

\section{Analisis Multivariat Seleksi Bivariat}

Tabel 9 Hasil seleksi bivariat variabel independent dengan variabel dependen

\begin{tabular}{ccc}
\hline Variabel & P value & Pvalue $<\mathbf{0 , 2 5}$ \\
\hline Usia & 0,185 & $\sqrt{ }$ \\
Pendidikan & 0,083 & $\sqrt{ }$ \\
Pekerjaan & 0,999 & $\mathrm{X}$ \\
Pengetahuan & 0,889 & $\mathrm{X}$ \\
Sikap & 0,031 & $\sqrt{ }$ \\
Perilaku & 0,001 & $\sqrt{ }$ \\
\hline
\end{tabular}

Hasil seleksi bivariat semua variabel menghasilkan $\mathrm{p}$ value $<0,25$, didapat variabel pekerjaan dan pengetahuan yang $p$ valuenya $>0,25$. Namun pengetahuan tetap dianalisis multivariat oleh karena secara substansi pengetahuan merupakan variabel yang sangat penting berhubungan dengan kejadian kepatuhan dalam pencegahan covid-19.

\section{Pemodelan Multivariat}

Tabel 10 Pemodelan regresi logistic pemodelan bersama

\begin{tabular}{ccccc}
\hline Variabel & B & Pvalue & OR & $\begin{array}{c}\mathbf{9 5 \%} \\
\text { CI }\end{array}$ \\
\hline Usia & $-0,557$ & 0,193 & 0,573 & $0,247-$ \\
Pendidikan & $-1,180$ & 0,210 & 0,307 & 1,326 \\
Pengetahuan & $-0,057$ & 0,902 & 0,944 & $0,049-$ \\
Sikap & 0,918 & 0,032 & 2,505 & 1,941 \\
Perilaku & 1,611 & 0,000 & 5,009 & $0,381-$ \\
& & & & 2,341 \\
& & & & $1,083-$ \\
& & & & 5,796 \\
& & & & $2,048-$ \\
& & & & 12,254 \\
\hline
\end{tabular}


Dilakukan eleminasi variabel yang $\mathrm{p}$ valuenya $>0,05$. Dari pemodelan pertama terlihat ada tiga variabel yang $\mathrm{p}$ valuenya $>$ 0,05 yauitu usia, pendidikan dan pengetahuan. Eliminasi pertama, variabel yang $\mathrm{p}$ valuenya $>0,05$ dan terbesar dikeluarkan dari model yaitu pengetahuan.

Tabel 11 Pemodelan regresi logistic pemodelan kedua

\begin{tabular}{ccccc}
\hline Variabel & B & Pvalue & OR & $\begin{array}{c}\text { 95\% } \\
\text { CI }\end{array}$ \\
\hline Usia & $-0,566$ & 0,181 & 0,588 & $0,248-$ \\
Pendidikan & $-1,208$ & 0,186 & 0,299 & 1,301 \\
Sikap & 0,925 & 0,029 & 2,523 & $0,050-$ \\
Perilaku & 1,630 & 0,000 & 5,102 & 1,788 \\
& & & & $1,098-$ \\
& & & & 5,794 \\
& & & & $2,187-$ \\
& & & & 11,902 \\
\hline
\end{tabular}

Hasil perhitungan perubahan nilai OR usia $(2,6 \%)$, pendidikan $(2,6 \%)$, sikap $(0,7 \%)$, perilaku $(1,8 \%)$. Sehingga pengetahuan tetap dikeluarkan dari model, eliminasi berikutnya adalah pendidikan.

Tabel 12 Pemodelan regresi logistic pemodelan ketiga

\begin{tabular}{ccccc}
\hline Variabel & B & Pvalue & OR & $\begin{array}{c}\mathbf{9 5 \%} \\
\text { CI }\end{array}$ \\
\hline Usia & $-0,578$ & 0,168 & 0,561 & $0,247-$ \\
Sikap & 0,967 & 0,021 & 2,631 & 1,276 \\
Perilaku & 1,625 & 0,000 & 5,081 & $1,157-$ \\
& & & & 5,982 \\
& & & & $2,196-$ \\
& & & & 11,752 \\
\hline
\end{tabular}

\section{PEMBAHASAN}

Hubungan Usia dengan Kepatuhan Ibu Rumah Tangga dalam Pencegahan Covid-19

Hasil uji yang dilakukan dalam penelitian ini didapatkan pvalue 0,336 (pvalue>0,05) menunjukan bahwa tidak ada hubungan yang bermakna antara karakteristik individu (usia) dengan kepatuhan ibu rumah tangga dalam pencegahan Covid-19. Hasil OR 0,655 dengan rentang confidence interval (CI)
Hasil perhitungan perubahan nilai OR usia $(2,0 \%)$, sikap $(5,0 \%)$, perilaku $(1,4 \%)$. Sehingga pendidikan tetap dikeluarkan dari model, eliminasi berikutnya adalah usia.

Tabel 13 Pemodelan regresi logistic pemodelan keempat

\begin{tabular}{ccccc}
\hline Variabel & B & Pvalue & OR & $\begin{array}{c}\text { 95\% } \\
\text { CI }\end{array}$ \\
\hline Sikap & 0,933 & 0,024 & 2,543 & $1,130-$ \\
Perilaku & 1,595 & 0,000 & 4,929 & 5,723 \\
& & & & $2,156-$ \\
\multicolumn{2}{c}{ Hasil } & perhitungan & perubahan nilai
\end{tabular}

OR sikap (1,5\%) dan perilaku (1,5\%). Dari analisis multivariat ternyata variabel yang berhubungan bermakna dengan kepatuhan ibu rumah tangga dalam pencegahan covid-19 adalah variabel sikap dan perilaku. Hasil analisis Odds Ratio (OR) dari variabel perilaku adalah 4,9 (95\% CI: 2,15-11,26), artinya ibu yang memiliki perilaku kurang baik akan mempunyai odds (berisiko) terhadap kepatuhan pencegahan covid-19 5 kali lebih tinggi dibandingkan ibu yang memiliki perilaku baik setelah dikontrol variabel sikap. Secara sama dapat diinterpretasikan untuk variabel lainnya. Variabel yang paling dominan berhubungan dengan kejadian kepatuhan dalam pencegahan covid-19 adalah perilaku.

0,318-1,352 menunjukan bahwa usia tidak berisiko terhadap kepatuhan pencegahan Covid-19.

Analisis multivariat yang telah dilakukan diatas, menunjukan bahwa tidak ada hubungan usia dengan kepatuhan dalam pencegahan Covid-19 dalam penelitian ini, untuk penelitian lebih lanjut perlu pemilihan populasi atau sampel kelompok usia lain untuk menemukan hubungan dengan kepatuhan dalam 
pencegahan Covid-19, misalnya: kelompok usia remaja.

Hasil penelitian diatas sejalan dengan hasil penelitian (Wulandari, dkk, 2020) yang berjudul "hubungan karakteristik individu dengan pengetahuan tentang pencegahan Coronavirus Disease 2019 pada masyarakat di Kalimantan Selatan". Ditunjukan usia dengan nilai pvalue $=0,386$ (pvalue 0,386>0,05), maka tidak ada hubungan antara umur dengan pengetahuan tentang pencegahan Covid19.

Dilihat dari mayoritas umur $\leq 45$ merupakan usia matang dengan pertimbangan seseorang pada umur tersebut akan memiliki pola tangkap dandaya pikir yang baik sehingga pengetahuan yang dimilikinya juga akan semakin membaik. Umur bukan menjadi faktor penghambat sumber informasi masyarakat untuk mendapatkan pengetahuan mengenai pencegahan Covid19, karena masyarakat dengan kategori umur yang berbeda memungkinkan untuk memiliki keaktifan dan keterpaparan informasi yang sama (Nurmala, 2018).

\section{Hubungan Pendidikan dengan Kepatuhan Ibu Rumah Tangga dalam Pencegahan Covid-19}

Hasil uji yang dilakukan dalam penelitian ini didapatkan pvalue 0,140 (pvalue>0,05) menunjukan bahwa tidak ada hubungan yang bermakna antara karakteristik individu (pendidikan) dengan kepatuhan ibu rumah tangga dalam pencegahan Covid-19. Hasil OR 0,259 dengan rentang confidence interval (CI) 0,050-1,341 menunjukan bahwa pendidikan tidak berisiko terhadap kepatuhan pencegahan Covid-19.

Analisis multivariat yang telah dilakukan diatas, menunjukan bahwa tidak ada hubungan pendidikan dengan kepatuhan dalam pencegahan Covid-19 dalam penelitian ini, untuk penelitian lebih lanjut perlu pemilihan populasi atau sampel remaja di sekolah dengan pendidikan yang setara untuk menemukan hubungan dengan kepatuhan dalam pencegahan Covid-19.

Hasil penelitian diatas sejalan dengan hasil penelitian (Wulandari, dkk, 2020) yang berjudul "hubungan karakteristik individu dengan pengetahuan tentang pencegahan Coronavirus Disease 2019 pada masyarakat di Kalimantan Selatan”. Ditunjukan pendidikan dengan nilai pvalue $=0,428$ (pvalue 0,428>0,05), maka tidak ada hubungan antara pendidikan dengan pengetahuan tentang pencegahan Covid-19.

Hal ini disebabkan karena informasi yang didapatkan oleh masyarakat dengan pendidikan rendah mengenai penularan Covid-19 tidak hanya dari pendidikan formal tetapi dari pengalaman dirinya maupun lingkungan kehidupan bermasyarakat sehingga masyarakat patuh karena cenderung khawatir dengan penularan Covid-19. Pendidikan yang cenderung rendah juga membuat kurangnya mendapatkan informasi kesehatan.

\section{Hubungan Pekerjaan dengan Kepatuhan Ibu Rumah Tangga dalam Pencegahan Covid-19}

Hasil uji yang dilakukan dalam penelitian ini didapatkan pvalue 0,093 (pvalue >0,05) menunjukan bahwa tidak ada hubungan yang bermakna antara karakteristik individu (pekerjaan) dengan kepatuhan ibu rumah tangga dalam pencegahan Covid-19. Hasil OR dengan rentang confidence interval (CI) menunjukan bahwa usia tidak berisiko terhadap kepatuhan pencegahan Covid-19. 
Analisis multivariat yang telah dilakukan diatas, menunjukan bahwa tidak ada hubungan pekerjaan dengan kepatuhan dalam pencegahan Covid-19 dalam penelitian ini, untuk penelitian lebih lanjut perlu pemilihan populasi atau sampel kelompok ibu rumah tangga yang bekerja untuk menemukan hubungan dengan kepatuhan dalam pencegahan Covid-19.

Hasil penelitian diatas sejalan dengan hasil penelitian (Wulandari, dkk, 2020) yang berjudul "hubungan karakteristik individu dengan pengetahuan tentang pencegahan Coronavirus Disease 2019 pada masyarakat di Kalimantan Selatan". Ditunjukan pendidikan dengan nilai pvalue=0,515 (pvalue 0,515>0,05), maka tidak ada hubungan antara pekerjaan dengan pengetahuan tentang pencegahan Covid-19.

Mayoritas responden tidak bekerja yaitu 117 responden $(97,5 \%)$ tetapi masyarakat dapat mendapatkan informasi mengenai Covid-19 bermacam-macam media massa yang setiap senantiasa memberikan informasi mengenai penyebaran dan pencegahan Covid-19 Status ekonomi seseorang juga menentukan tersedianya suatu fasilitas yang diperlukan untuk kegiatan tertentu sehingga status sosial ekonomi akan mempengaruhi pengetahuan seseorang, faktor lingkungan dimana merupakan segala sesuatu yang ada disekitar individu, baik fisik, biologis maupun sosial, lingkungan berpengaruh terhadap proses masuknya pengetahuan kedalam individu yang berada dalam lingkungan tersebut hal ini dikarenakan adanya interaksi timbal balik dalam lingkungan, mayoritas responden cukup khawatir dengan kondisi penyebaran Covid-19 saat ini yaitu 65 responden sehingga responden patuh dalam melakukan pencegahan Covid-19.

\section{Hubungan Pengetahuan dengan Kepatuhan Ibu Rumah Tangga dalam Pencegahan Covid-19}

Hasil uji yang dilakukan dalam penelitian ini didapatkan pvalue 0,024 (pvalue<0,05) menunjukan bahwa ada hubungan yang bermakna antara pengetahuan dengan kepatuhan ibu rumah tangga dalam pencegahan Covid-19. Hasil OR 0,399 dengan rentang confidence interval (CI) 0,190-0,838 menunjukan bahwa pengetahuan tidak berisiko terhadap kepatuhan pencegahan Covid-19.

Analisis multivariat yang telah dilakukan diatas, menunjukan bahwa tidak ada hubungan pengetahuan dengan kepatuhan dalam pencegahan Covid-19 dalam penelitian ini, untuk penelitian lebih lanjut perlu pemilihan populasi atau sampel remaja untuk menemukan hubungan dengan kepatuhan dalam pencegahan Covid-19.

Hasil penelitian dengan uji chisquare diatas sejalan dengan hasil penelitian (Zulhafandi, 2020) yang berjudul "hubungan pengetahuan tentang Covid-19 dengan kepatuhan physical distancing di Tarakan". Ditunjukan pengetahuan dengan nilai pvalue $=0,00$ (pvalue $0,00<0,05$ ), maka ada hubungan yang significant antara tingkat pengetahuan tentang Covid-19 dengan kepatuhan melakukan physical distancing di kota Tarakan.

Pengetahuan dipengaruhi oleh beberapa faktor yaitu faktor pendidikan yang merupakan suatu usaha untuk mengembangkan kepribadian dan kemampuan didalam dan diluar sekolah baik formal maupun non formal dan berlangsung seumur hidup disebutkan bahwa makin tinggi pendidikan seseorang maka semakin mudah orang tersebut menerima informasi, faktor infomasi/media masa dengan 
berkembangnya teknologi akan menyediakan bermacam-macam media massa yang dapat mempengaruhi pengetahuan masyarakat tentang informasi terbaru, sehingga saran komunikasi seperti televisi, radio, surat kabar, majalah dan lain lain mempunyai pengaruh besar terhadap penyampaian opini dan kepercayaan sesorang (Aryanti, 2020).

Sumber pengetahuan terkait dengan Covid-19 didapatkan dari media social, internet, televisi, kementrian kesehatan, WHO dan informasi teman (Alzoubi, et al., 2020). Hingga saat ini artikel ini ditulis pemerintah Indonesia bersama kementrian kesehatan melakukan tindakan-tindakan signifikan pemberian informasi guna peningkatan pengetahuan terkait dengan edukasi pencegahan penularan virus Covid 19 dan bahaya covid 19 pada masyarakat melalui media social, televisi surat kabar. Pemerintah memberikan edukasi pada masyarakat terkait protocol kesehatan saat bertemu dengan orang lain seperti selalu memakai masker, menjaga jarak minimal1 meter, dan selalu cuci tangan menggunakan sabun (Mas'udi \& Winanti, 2020).

Pengetahuan merupakan factor esensial yang dapat mempengaruhi perubahan perilaku, dan individu dapat memperoleh pengetahuan dan ketrampilan melalui proses belajar (Liuetal,2016). Dengan demikian pengetahuan masyarakat yang masih perlu diluruskan dan perilaku kepatuhan masyarakat yang masih negative dapat diupayakan dengan kegiatan pembelajaran melalui edukasi oleh pihakpihak yang berwenang. Dalam masyarakat, forum Kesehatan desa atau sejenisnya dapat mengambil peran dalam upaya pelaksanaan kegiatan dimaksud.

\section{Hubungan Sikap dengan Kepatuhan Ibu} Rumah Tangga dalam Pencegahan Covid-19

Hasil uji yang dilakukan dalam penelitian ini didapatkan pvalue 0,002 (pvalue<0,05) menunjukan bahwa ada hubungan yang bermakna antara sikap dengan kepatuhan ibu rumah tangga dalam pencegahan Covid-19. Hasil OR 3,392 dengan rentang confidence interval (CI) 1,599-7,199 menunjukan bahwa sikap berisiko terhadap kepatuhan pencegahan Covid-19.

Analisis multivariat yang telah dilakukan diatas, menunjukan bahwa ada hubungan sikap dengan kepatuhan dalam pencegahan Covid-19 dalam penelitian ini, ibu yang memiliki sikap negative akan mempunyai odds (berisiko) terhadap kepatuhan pencegahan covid-19 3 kali lebih tinggi dibandingkan ibu yang memiliki perilaku baik (95\% CI: 1,135,72).

Hasil penelitian ini mendukung penelitian yang dilakukan (Aakash, A.R, 2020) menemukan bahwa Sebagian besar responden memiliki sikap negatif terhadap pengendalian situasi Covid-19 sehingga terdapat hubungan sikap dengan cara pengendalian Covid-19. Sedangkan hasil penelitian pendukung lainnya yang dilakukan (Lestari, 2019) menyatakan bahwa dari nilai signifikan $\mathrm{p}=0.013$ (sig $<0,05$ ) yang berarti terdapat hubungan antara sikap dengan tindakan cuci tangan dalam pencegahan Covid-19.

Sikap seseorang akan memengaruhi tindakan kesehatan, minat untuk bertindak positif seseorang akan menghasilkan tindakan kesehatan yang positif pula. Pembentukan sikap dipengaruhi beberapa faktor, yaitu pengalaman pribadi, kebudayaan, orang lain yang dianggap penting, media massa, institusi atau 
lembaga pendidikan dan lembaga agama, faktor emosi dalam diri individu (Azwar, 2013).

Sikap merupakan keteraturan antara komponen-komponen pemikiran, hal perasaan dan predisposisi tindakan yang saling berinteraksi, memahami, merasakan dan berperilaku terhadap suatu objek lingkungan di sekitarnya. Menurut asumsi peneliti, sikap yang baik akan sangat mempengaruhi kepatuhan dalam pencegahan Covid-19. Sikap yang baik akan menjadi pendukung untuk menjalani pencegahan Covid-19. Jadi dapat disimpulkan bahwa ada hubungan yang signifikan antara sikap dengan kepatuhan ibu rumah tangga dalam pencegahan Covid-19.

\section{Hubungan Perilaku dengan Kepatuhan Ibu Rumah Tangga dalam Pencegahan Covid-19}

Hasil uji yang dilakukan dalam penelitian ini didapatkan pvalue 0,000 (pvalue<0,05) menunjukan bahwa ada hubungan yang bermakna antara perilaku dengan kepatuhan ibu rumah tangga dalam pencegahan Covid-19. Hasil OR 5,898 dengan rentang confidence interval (CI) 2,641-13,172 menunjukan bahwa perilaku berisiko terhadap kepatuhan pencegahan Covid-19.

Analisis multivariat yang telah dilakukan diatas, menunjukan bahwa ada hubungan perilaku dengan kepatuhan dalam pencegahan Covid-19 dalam penelitian ini, ibu yang memiliki perilaku

\section{KESIMPULAN}

1. Distribusi frekuensi karakteristik individu mayoritas usia responden berada pada usia $\leq 45$ tahun sebanyak 63 orang yaitu (52,5\%), mayoritas berpendidikan rendah sebanyak 43 orang yaitu $(35,8 \%)$, dan mayoritas kurang baik akan mempunyai odds (berisiko) terhadap kepatuhan pencegahan covid-19 5 kali lebih tinggi dibandingkan ibu yang memiliki perilaku baik (95\% CI: 2,15-11,26).

Hasil penelitian ini didukung oleh penelitian yang dilakukan (Candra, 2020) berdasarkan hasil uji Chi-square maka dapat diketahui bahwa terdapat hubungan yang bermakna $(p=0,000<0,05)$ antara perilaku dengan kepatuhan menggunakan APD.

Perilaku yang baik dapat menjadi upaya pencegahan terhadap penularan covid19 (Audria,2019). Perilaku Kesehatan dipengaruhi oleh banyak factor, diantaranya pengetahuan, persepsi, emosi, motivasi, dan lingkungan (Rahayu,2014). Eksplorasi tentang perilaku Kesehatan masyarakat dapat dilihat dari berbagai komponen, diantaranya persepsi tentang kerentanan penyakit, persepsi hambatan dalam upaya pencegahan, persepsi tentang manfaat, adanya dorongan, dan persepsi individu tentang kemampuan yang dimiliki untuk melakukan upaya pencegahan (Almi,2020).

Menurut teori Lewin dalam Notoatmodjo (2007), seseorang berupaya untuk mengobati dan mencegah penyakit, ia harus merasakan bahwa ia rentan terhadap penyakit tersebut (susceptible) yang berarti bahwa suatu upaya pencegahan terhadap suatu penyakit akan timbul jika seseorang merasa rentan terhadap penyakit tersebut.

pekerjaan responden adalah tidak bekerja sebanyak 117 orang yaitu $(97,5 \%)$.

2. Distribusi frekuensi responden memiliki tingkat pengetahuan tinggi sebanyak 64 orang yaitu $(53,3 \%)$, 
mayoritas responden memiliki sikap positif sebanyak 65 orang yaitu (54,2\%), mayoritas responden memiliki perilaku baik sebanyak 72 orang yaitu (60\%), dan mayoritas responden patuh dalam pencegahan covid-19 sebanyak 65 orang yaitu $(54,2 \%)$.

3. Tidak ada hubungan karakteristik individu dengan kepatuhan ibu rumah tangga dalam pencegahan Covid-19 di RT 02 RW 05 Kabandungan 1 Desa Sirnagalih.

\section{DAFTAR PUSTAKA}

Aakash, A.R. 2020. Knowledge, Attitude, and Preventive Practices toward COVID-19 among Bangladeshi Internet Users. https://www.researchgate.net/publica tion/341050342_Knowledge_Attitud e_and_Preventive_Practices_toward COVID19_among_Bangladeshi_Inte rnet_Users. Diakses pada tanggal 30 September 2020 Pukul 21.00 WIB

Alfaqinisa, rara. 2015. Hubungan Antara Tingkat Pengetahuan, Sikap,Dan Perilaku Orang Tua Tentang Pneumonia Dengan Tingkat Kekambuhan Pneumoniapada Balitadi Wilayah Kerja Puskesmas Ngesrepkota Semarang Tahun 2015. Skripsi.

https://lib.unnes.ac.id/22943/1/64114 11240.pdf. Diakses pada tanggal 11 September 2020 Pukul 20.00 WIB.

Aminudin, M. 2016. Hubungan Antara Pengetahuan Dan Sikap Dengan Perilaku Konsumsi Jajanan Sehat Di Mi Sulaimaniyah Mojoagung Jombang. Skripsi. http://repository.unair.ac.id/46023/2/
4. Tidak ada hubungan pengetahuan dengan kepatuhan ibu rumah tangga dalam pencegahan Covid-19 di RT 02 RW 05 Kabandungan 1 Desa Sirnagalih.

5. Ada hubungan sikap dengan kepatuhan ibu rumah tangga dalam pencegahan Covid-19 di RT 02 RW 05 Kabandungan 1 Desa Sirnagalih.

6. Ada hubungan perilaku dengan kepatuhan ibu rumah tangga dalam pencegahan Covid-19 di RT 02 RW 05 Kabandungan 1 Desa Sirnagalih.

FKM.\%20290-16\%20Feb\%20h.pdf. Diakses pada tanggal 10 September 2020 Pukul 20.00 WIB.

Candra, evi. 2020. Faktor-Faktor Yang Berhubungan Dengan Perilaku Kepatuhan Penggunaan Apd. http://stikesayani.ac.id/publikasi/ejournal/filesx/2009/200904/200904004.pdf. Diakses pada tanggal 30 September 2020 Pukul 20.00 WIB

Durisah. 2016. Hubungan Tingkat Pengetahuan Dan Sikap Dengan Perilaku Remaja Putri Tentang Kebersihan Organ Reproduksi Pada Saat Menstruasi Di Smp Pesantren Pancasila Kota Bengkulu Tahun 2016.

Skripsi.http://repository.unived.ac.id/ 43/1/DURISAH\%20NPM.12242601 4.SM.pdf. Diakses pada tanggal 11 September 2020 Pukul 19.00 WIB.

Gugus Tugas Percepatan Penanganan COVID-19. Data Sebaran Covid-19. Data Sebaran.

Ihsan S, dkk. 2020. Penguatan Peran Warga Masyarakat Dalam Mitigasi 
Dan Adaptasi Menghadapi Wabah Covid-19 Di Kabupaten Konawe Kepulauan Provinsi Sulawesi Tenggara. Jurnal Pengabdian Masyarakat anoa.

Kementerian Kesehatan. protokol COVID19. drg. Widyawati, MKM.

Pasanda, M. 2016. Perbedaan Pengetahuan, Sikap Dan Perilakupenjamah Makanan Sesudah Diberikan Penyuluhan Personal Hygienedi Hotel Patra Jasa Semarang. Skripsi. http://repository.unimus.ac.id/93/1/S KRIPSI\%20FULL\%20TEXT.1.pdf.

Diakses pada tanggal 10 September 2020 Pukul 20.00 WIB.

Purnamasari I, Anisa E. 2020. Tingkat Pengetahuan dan Perilaku Masyarakat Kabupaten Wonosobo Tentang Covid-19. Jurnal Ilmu Kesehatan.

Saefi M, dkk. 2020. Survey Data of COVID 19 Related Knowledge, Attitude, and Practices among Indonesian Undergraduate Students. https://www.sciencedirect.com/scien ce/article/pii/S2352340920307496.

Diakses pada tanggal 5 September 2020 Pukul 20.00 WIB.

Sanifah, Laili. 2018. Hubungan Tingkat Pengetahuan Dengansikap Keluarga Tentangperawatan Activities Daily Living(Adl) Pada Lansia. Skripsi. http://repo.stikesicmejbg.ac.id/1312/ 2/143210125\%20LAILI\%20JAMIL
ATUS\%20SANIFAH\%20\%20skrips i.pdf. Diakses pada tanggal 13 September 2020 Pukul 19.00 WIB.

Susilo A, dkk. 2020. Coronavirus Disease 2019: Tinjauan Literatur Terkini. https://www.researchgate.net/publica tion/340380088_Coronavirus_Diseas e_2019_Tinjauan_Literatur_Terkini. Diakses pada tanggal 6 September 2020 Pukul 19.00 WIB.

Tynan m, dkk. 2020. Public Attitudes, Behaviors, and Beliefs Related to COVID-19, Stay-at-Home Orders, Nonessential Business Closures, and Public Health Guidance - United States, New York City, and Los Angeles.

https://www.cdc.gov/mmwr/volumes 169/wr/mm6924e1.htm. Diakses pada tanggal 9 September 2020 Pukul 20.00 WIB.

WHO. Coronavirus disease (COVID-19) outbreak. Emergencies - Diseases.

Wulandari, dkk. 2020. Hubungan Karakteristik Individu dengan Pengetahuan tentang Pencegahan Coronavirus Disease 2019 pada Masyarakat di Kalimantan Selatan. https://www.researchgate.net/publica tion/341836509_Hubungan_Karakter istik_Individu_dengan_Pengetahuan tentang_Pencegahan_Coronavirus_ Disease_2019_pada_Masyarakat_di Kalimantan_Selatan. Diakses pada tanggal 30 September 2020 Pukul 17.00 WIB. 